\title{
Corporate takeovers in the US oil and gas sector
}

\author{
Alex Ng a ${ }^{*}$, Raymond A. K. Cox ${ }^{b}$ \\ a Thompson Rivers University, Associate Professor of Finance, British Columbia, Canada. \\ b Thompson Rivers University, Chair and Professor of Finance, Department of Accounting \& Finance, British Columbia, Canada. \\ *Corresponding author's email address: ang@tru.ca
}

\section{A R T I C LE IN F O}

Received: 07-01-2016

Accepted: 27-02-2016

Available online: 08-03-2016

Keywords:

Mergers and acquisitions;

Oil and gas;

Reserves energy;

Takeovers.

JEL Classification:

G12; G34; L71; M20 ; Q40.

\begin{abstract}
A B S T R A C T
We examine corporate takeovers in the U.S. oil and gas sector from 1990 to 2008 . We test the hypotheses that energy prices and reserves influence takeovers in the energy market for corporate control. We employ these methods: 1 . capital asset pricing model, 2 . regression analysis, and 3. Granger causality test. Our results show that oil reserves cause takeover deals and affect the value of the merger. High oil prices propel management to acquire oil firms as well as affect the target value. However, the reverse cause-effect mechanism occurs for natural gas prices. That is, takeover activity causes gas prices to decrease. Acquirers are motivated to purchase reserves; whereas, targets are disposed to sell based on energy prices. Hence, our findings imply that countries can consider policies, which address the motivations of the oil and gas industries to facilitate well-functioning takeover markets.
\end{abstract}

(C) 2016 The Authors. This is an open access article under the terms of the Creative Commons Attribution License 4.0, which allows use, distribution and reproduction in any medium, provided the original work is properly cited.

DOI: http://dx.doi.org/10.18533/jefs.v4i1.208

\subsection{Introduction}

Commodity markets have major impacts on the capital markets and economy. More specifically, the oil and gas ( 0 \& G) sector of the energy industry has been the propelling force causing swings in the business cycle from boom to recession and back. In the currency market, numerous foreign-exchange rates move in response to changes in the prices of oil and gas. The operating performance of industries such as airlines is highly dependent on the input costs of fuel derived from oil. Recently Saudi Arabia has driven down the price to retain customers and market share and to drive out competitors. In particular, the previous high oil prices has made it attractive for oil and gas fields' development especially in the US gas shale industry. As a result, the US became a net exporter of oil for the first time in decades. Do events occurring in the 0 \& G sector affect financial decision-making? Our study focuses on the takeover activities of O \& G firms in the U.S. from 1990 to 2008. We present evidence that energy reserves and commodity prices modify takeover behavior. Managers can be motivated to purchase (or sell) 0 \& G companies dependent on the level of $O \&$ G reserves and prices.

The mergers and acquisitions (M\&A) literature has an extremely long tradition [Martynova28] with recurring themes, such as agency costs, merger waves, performance, payment options, market power, synergy effects, stock market driven acquisition, and managerial objectives. The impact of energy markets is fundamental to the world economy and influences inflation, monetary policy, economic growth and wealth.

Weston, et al. (1990) argue that takeover activities have been high in industries undergoing deregulation, experiencing oil price shocks, or facing structural alteration. Jensen (1993) and Mitchell and Mulherin (1996) demonstrate that M \& A activities were driven by economic shocks in the industry, including oil shocks. Our 
motivation to study corporate takeovers in the oil and gas industry is that there could be different motives for takeovers compared to other industries. Donker and Ng (2013) first discover acquiring reserves and commodity price driven motivation for oil and gas takeovers recently in the Canadian market. In our study, we examine these new motivations in the US O \& G sector, which remains unexamined. Our study is particularly relevant to the US oil and gas industry, which is experiencing one of its largest expansions in history.

Our contribution to the literature is to demonstrate that the US 0 \& G corporations are: 1 . motivated to consummate takeovers to purchase reserves, 2 . takeovers are connected to energy prices as well as firm value, 3 . acquirer firm stockholder's wealth significantly decreases during the announcement period of takeovers (while target wealth increases significantly) and 4 . Commodity price-driven takeovers are different from stock marketdriven takeovers.

We find US acquirers incur negative returns when announcing an acquisition, controlled for beta risk and the stock market, as other acquirers do in other sectors. The valuation of M \& A deals is negatively (positively) tied to oil (gas) reserves. Further, the level of oil prices positively affects the number of M \& A deals. Our findings imply that for countries with an interest in promoting their energy industry, can evaluate and consider policies, which address the motivations of the oil and gas industries to facilitate well-functioning takeover markets.

We organize the rest of the paper as follows. In Section two, we discuss the literature. Section three we develop our hypotheses. Section 4 contains our sample selection and research design. In Section five, we discuss our empirical findings. We conduct robustness tests in Section 6 and we conclude and present policy implications in Section 7.

\subsection{Literature review}

The literature recognizes these motivations for managers to engage in M \& A. Bruner's (2002) survey shows managers seek to create synergies to improve firm value and from attaining economies of scale. Jensen and Meckling (1976) articulate that managers engage in takeovers because they benefit themselves as agents at the likely expense of decreasing shareholder value. Jensen (1986) posits that managers of firms with rich cash flows, as with oil and gas firms, are known to expend them on value destroying M \& A. Dong et al. (2006), Rhodes-Kropf et al. (2005) and Shliefer et al. (2003) present evidence that agent motivated takeover occurs when managers take advantage of high stock prices of their firms to buy other companies relatively cheaply. Fan et al. (2013) show that for overvalued firms, takeovers profit the manager with higher compensation at the expense of shareholders in which there are no synergy gains for the firm and significant overpayment for the target.

Weston, et al. (1990) examine mergers and restructuring in the global oil industry in the 1990s. There is a high degree of consolidation, and the basic change forces responsible are technological advances, globalization, and deregulation. They conclude that instability in oil prices triggers M\&A and restructuring. Ferguson and Popkin (1982) observe that managers of oil firms pay excessive takeover premiums for their targets in their examination of the deal between Conoco and Marathon Oil. In their analysis, they show that when an acquirer can increase tax deductions such as depreciation and depletion, the acquirer can possibly gain at the expense of the government. By purchasing a target for its reserves, it is possible for an oil company to make a risk-free profit. Ng and Donker (2013) find that oil and gas reserves and prices cause and affect takeover activity, value, and performance in the Canadian energy industry. They conclude that acquirers are motivated to purchase reserves using takeovers.

Servaes (1994) finds that oil firms tend to overinvest their capital expenditures in the years leading up to takeovers. Ruback (1983), and Wan et al. (2009) explore case studies on oil takeovers. Reid (1973) examines the capital budgeting consequences arising from 0 \& G takeovers.

\subsection{Hypotheses development}

\subsection{Stock performance}

When acquirers purchase a firm for its reserves, they lower business risk, raise production, and increase assets. This reduction in business risk results in a decline in market risk along with a commensurate trimming in stock return. Boyer and Filion (2007) support this theorizing empirically whereby firms who increased their oil and/or gas production suffered lower stock returns. They explained the cause of this outcome is the exercise of real options to produce more energy that decreased the risk and so too should the return. This leads to hypothesis 1:

H1: Oil and gas acquirer's stock return declines subsequent to a takeover

\subsection{Purchasing reserves motivation}


Kretzschmar and Kirchner (2009) provide market evidence of the effects of reserves location and oil prices on 0 \& G company returns. 0 \& G firm valuation is dependent on reserves. Reserves are the amount of proven and probable stocks that are profitable to extract using available technology. Proven reserves can change in the longterm because of changes in 0 \& G prices, the advancement of extraction technologies, changes in extraction costs, discoveries of new stocks, and the depletion of current stocks.

Figure 1 clearly shows that energy reserves become more valuable over time. This figure also presents the average firm value of proven O\&G reserves worldwide from 2001 to 20091.

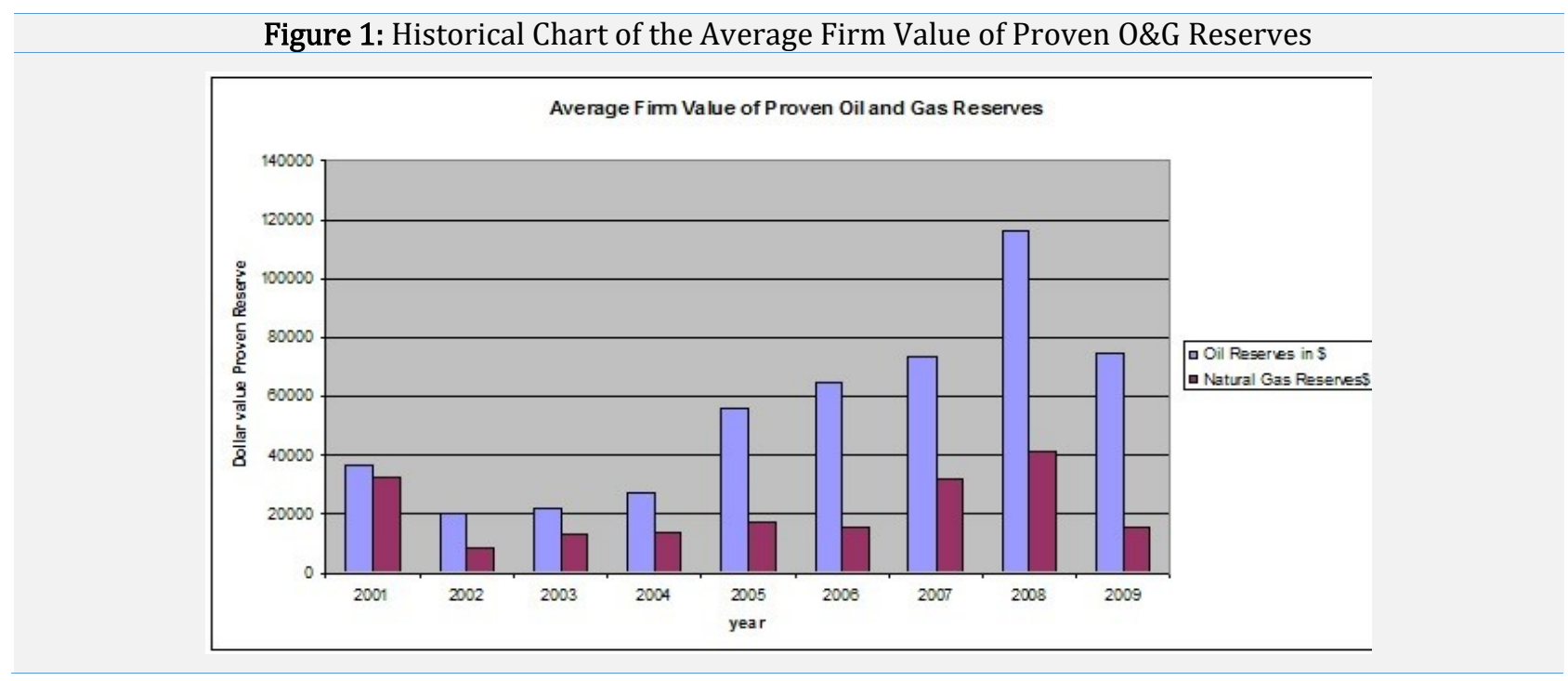

The fact that average proven reserves have increased over time supports our notion that managers have a strong rationale to purchase reserves through M\&A because they are an appreciating asset that increases shareholder wealth in the long run.

Figure 2 presents oil and gas takeover deals and energy reserves for oil and gas. As shown, O\&G reserves display a negative downward sloping trend, while takeover deals show a positive upward sloping trend. Thus, we suggest that diminishing reserves are related to takeovers. Natural gas reserves appear to trend positively and moves with the number of M\&A deals. There appears to be a positive relationship between natural gas reserves and takeovers. Therefore, our second hypothesis is:

H2: Energy reserves relate to takeover activities, value and performance

Figure 2: $0 \& G$ Reserves and Takeover Activity, United States

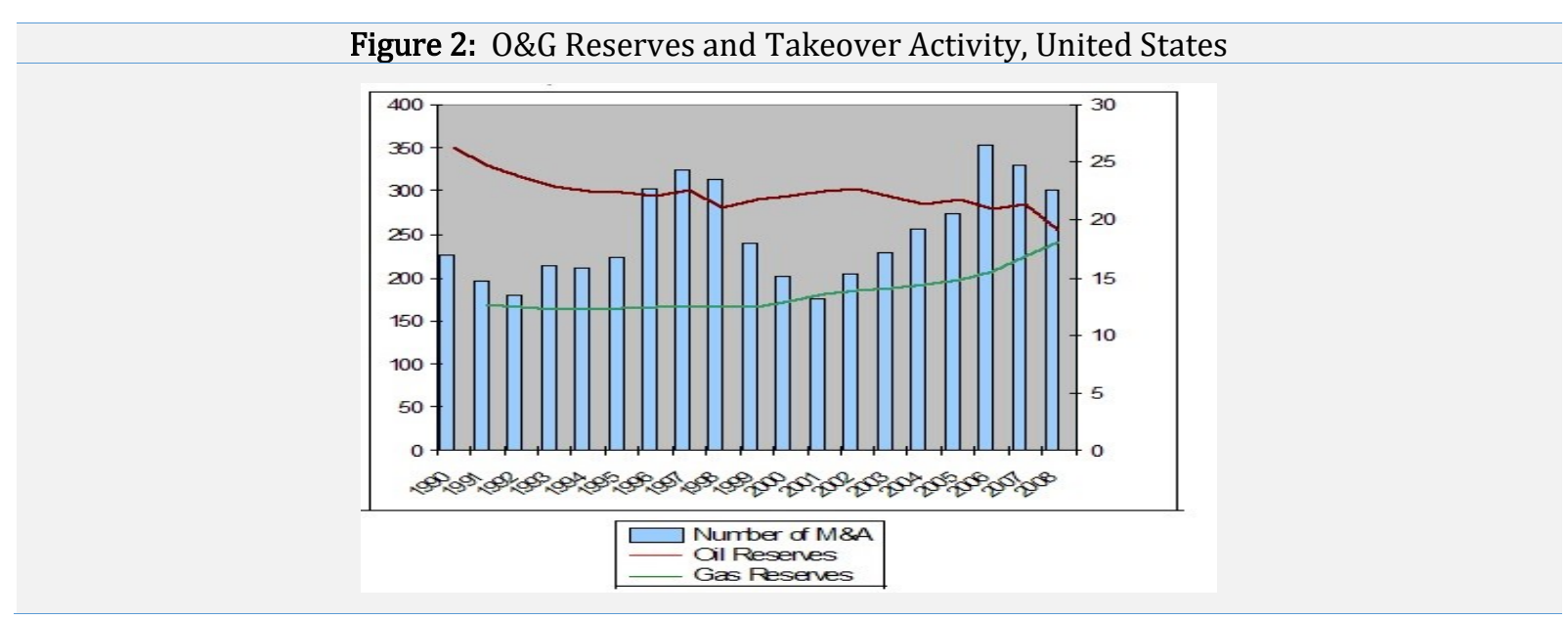

This chart presents takeover activity and industry data on proven O\&G reserves for US O\&G firms.

3.03 Commodity prices motivation

\footnotetext{
${ }^{1}$ Data are aggregated O\&G firms' average proven reserves obtained from Capital IQ. Average firm proven reserves represent a worldwide industry average.
} 
Acquirers may be interested in undertaking a merger when their stock price is high and/or the target stock price is low. Studies supporting this stock market price rationale include Shleifer and Vishny (2003), Rhodes-Kropf et al. (2005), and Dong et al. (2013). Further, Graham and Harvey (2001) surveyed managers who conceded to issuing equity to take advantage of market timing. Baker and Wurgler (2002) give additional evidence endorsing managers employing market timing in selling and buying back their firm's stock. While there are studies supportive of market timing of stock prices in the M\&A literature, the notion of managers timing oil and gas commodity prices for takeovers is new and clearly relevant to the energy industry.

Figure 3 illustrates the history of annual takeover activity during this sample period with an overlay of historical crude oil spot prices. We can see a pronounced takeover wave that moves closely with the rise in crude oil prices in 1998 to 2008. While there is an earlier takeover wave between 1995 and 1998, there does not appear to be a corresponding rise in oil prices.

Figure 3: Mergers, acquisition deals, and oil prices

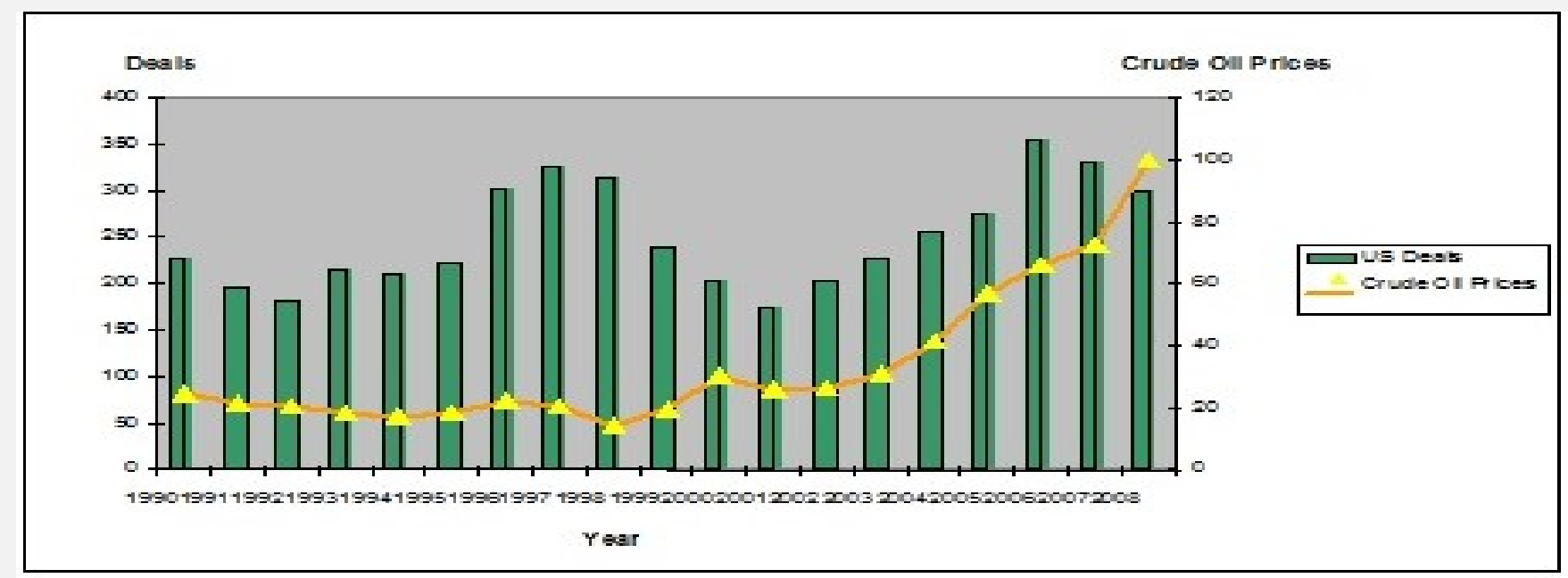

Figure 4 illustrates a history of takeover deal values with historical crude oil spot prices. Examining this figure gives intuition to our hypothesis that energy prices affect deal value and takeover performance. We can clearly see two waves of deal values, 1998 to 2001 and 2003 to 2008. Average deal values move closely with the rise and fall in crude oil prices during these takeover waves.

Figure 4: M \& A Deal Values and Energy Prices in the United States

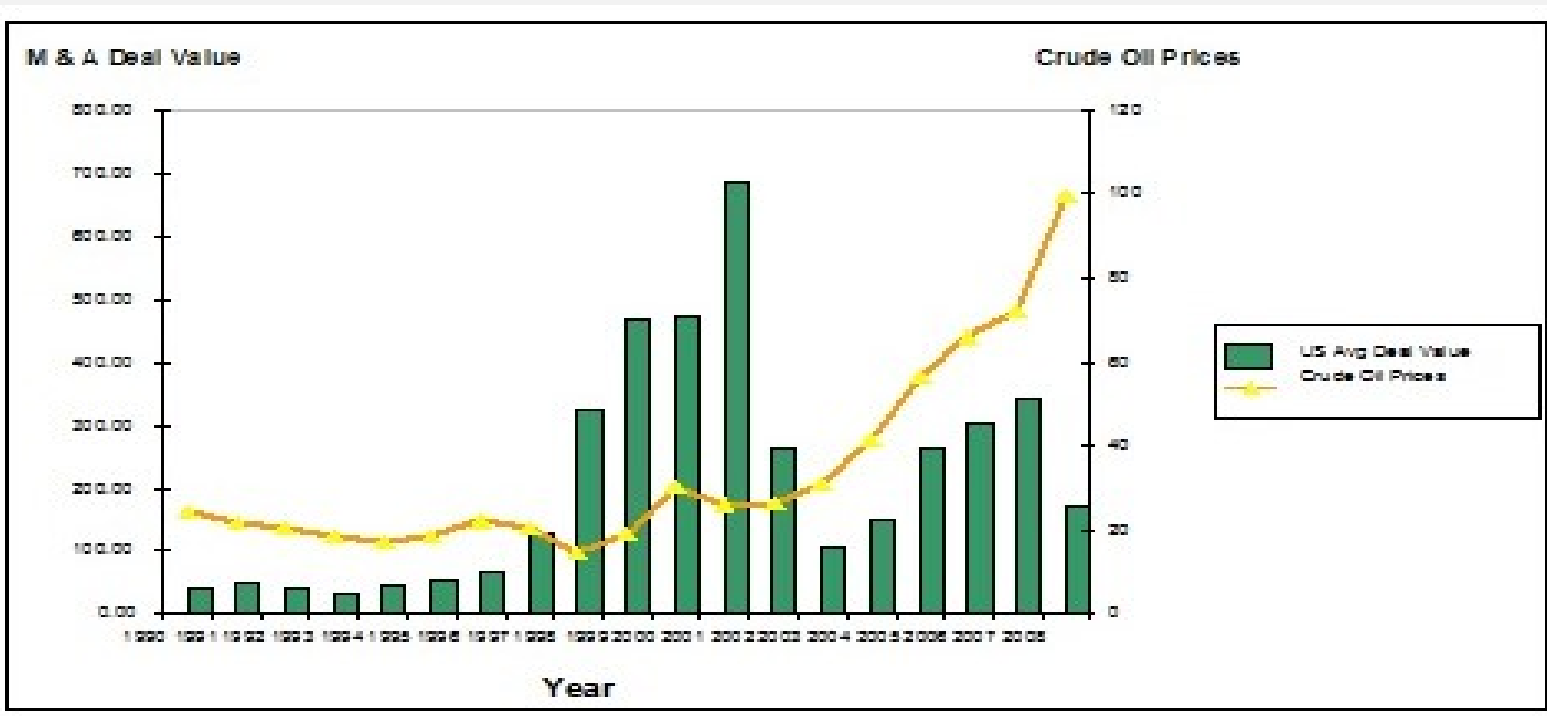

This leads us to hypothesis 3 , the commodity prices driven motivation:

H3: Energy prices relate to takeover activity, value and performance 


\subsection{Sample and variables}

We began by collecting all M\&A deals that occurred in the United States between January 1, 1990 and December 31, 2008 from the Thompson One Banker database excluding the period post-financial crisis. For the energy sector, we include only deals whose acquirer or target have a primary Standard Industrial Classification (SIC) codes corresponding to the energy sector (SIC numbers 1311, 1381, 1382, 1389, 2911, 2990, 4610, 4922, 4923, and 4924).

We eliminate incomplete deals, as well as share repurchases, self-tender offers, and non-controlling stake purchases along with deals in which there were insufficient deal information like discontinuous trading or no stock return. All firms are listed on the New York Stock Exchange (NYSE), NASDAQ, or American Stock Exchange (AMEX). In addition, the sample reduces if the firm stock price fell below $\$ 5$ per share, or the acquirer return on assets (ROA) is $100 \%$ or more (outlier). Stock return data came from Datastream. Our final sample is 183 firms. Table I provides a breakdown of the number of deals and total deal value by year. Appendix 1 provides variable definitions.

\begin{tabular}{|c|c|c|c|c|c|}
\hline \multirow[t]{2}{*}{ Year } & \multirow[b]{2}{*}{ Number } & \multicolumn{4}{|c|}{ Acquirer Country } \\
\hline & & $\begin{array}{r}\text { Total Value } \\
\text { (USD M) }\end{array}$ & U.S. & Foreign & Undisclosed \\
\hline 1990 & 226 & 9,002 & 199 & 20 & 9 \\
\hline 1991 & 195 & 9,320 & 187 & 9 & 12 \\
\hline 1992 & 180 & 7,178 & 166 & 5 & 13 \\
\hline 1993 & 214 & 6,700 & 200 & 10 & 7 \\
\hline 1994 & 211 & 9,398 & 197 & 8 & 10 \\
\hline 1995 & 223 & 11,594 & 209 & 11 & 10 \\
\hline 1996 & 302 & 20,711 & 291 & 9 & 16 \\
\hline 1997 & 324 & 41,480 & 295 & 14 & 19 \\
\hline 1998 & 314 & 101,061 & 296 & 15 & 14 \\
\hline 1999 & 239 & 111,825 & 233 & 12 & 4 \\
\hline 2000 & 202 & 95,034 & 194 & 21 & 14 \\
\hline 2001 & 175 & 120,081 & 179 & 16 & 9 \\
\hline 2002 & 204 & 53,205 & 178 & 14 & 23 \\
\hline 2003 & 228 & 24,049 & 206 & 5 & 11 \\
\hline 2004 & 257 & 38,542 & 237 & 13 & 14 \\
\hline 2005 & 274 & 71,784 & 243 & 22 & 14 \\
\hline 2006 & 354 & 107,392 & 310 & 36 & 14 \\
\hline 2007 & 330 & 112,338 & 278 & 38 & 39 \\
\hline 2008 & 100 & 17,005 & 87 & 10 & 14 \\
\hline Total & 4552 & 967,697 & 4185 & 288 & 266 \\
\hline Median & 226 & 38542 & 206 & 13 & 14 \\
\hline Mean & 240 & 50931 & 220 & 15 & 14 \\
\hline
\end{tabular}

\subsection{Estimation techniques}

For testing H1, we use a standard event study methodology, market model, from Brown and Warner (1985) to measure the abnormal daily returns around the announcements of a takeover. For the market return benchmark, we use two stock market return indexes, the Russell 1000, and the Standard and Poor's 500. The estimation period is 180 trading days prior to 30 days before the merger announcement day. The event window for abnormal returns is between 15 days before and after the merger announcement.

For testing H2, we determine whether a time series of crude oil and natural gas reserves have a causality effect on takeover activity, value, and performance using the Granger causality test. Historical data (1990-2008) consist of annual crude oil reserves levels and natural gas reported by the US Energy Information Administration. We measure takeover activity as the annual number of $\mathrm{M} \& \mathrm{~A}$ deals. We measure takeover value as the average annual deal value calculated as the total value of takeovers divided by the number of completed deals.

For testing H3, we examine the time series of average annual spot price quotes for West Texas Intermediate (WTI) crude oil and Henry Hub Natural Gas from the US Energy Information Administration with lagged values of the yearly number of M \& A deals. Specifically, the 0 \& G price changes are relative to the year of the M \& A deal; for example, $\mathrm{P} 0-\mathrm{P} 2$ denotes the change in the $0 \& \mathrm{G}$ price between the year of the merger and the price two years before the merger. 
We use the Granger causality test to assess whether energy prices positively relate to takeover performance at the industry level. We define takeover performance as the short-term cumulative average abnormal returns CAAR for both acquirers and targets.

Lastly, we use regression analyses to study the effects of reserves and market timing of energy prices on takeover performance. We define a proxy measure for firm-level reserves as the fixed asset ratio (calculated as fixed assets divided by total assets) controlling for size, profit, leverage, deal value, payment, tender or merger, free cash flow, and the market-to-book value ratio.

\subsection{Results}

\subsection{Takeover performance in the oil industry}

Table 2 shows the announcement effect of takeovers on oil and gas stockholder wealth. The cumulative average abnormal returns for US acquirers is significantly negative by one to two percent with CAAR windows of $(-1,+1)$, $(0,+1),(0,+3)$, and $(0,+5)$. Given the insignificant, but still negative sign, CAAR windows of $(-1,0)$ lends support to no information leakage prior to the M \& A event announcement. The insignificant CAAR of 0.03 for the (-10, +10 ) window suggests the impact of the event is short-lived.

Thus, these results clearly support hypothesis 1 ; namely, we accept that oil and gas acquirer's stock return declines subsequent to a takeover. In contrast, the US targets greatly benefit from M \& A announcements with positive returns with statistical significance (alpha equal to 1\%) for all event windows regardless if the acquirer is domestic or foreign. When the acquirer is foreign, it appears that abnormal returns are much lower than when the acquirer is a domestic US company. US target shareholders gain from as much as 8 to 22 percent from takeover announcements.

Table 2: Cumulative average abnormal returns for acquirers and targets

\begin{tabular}{|c|c|c|c|c|c|c|c|c|}
\hline \multirow[b]{4}{*}{ Event Windows } & \multicolumn{8}{|c|}{ Table 2: Cumulative average abnormal returns for acquirers and targets } \\
\hline & \multirow[b]{3}{*}{ Mean (\%) } & \multirow[b]{3}{*}{$\%+$} & \multirow{2}{*}{\multicolumn{2}{|c|}{ U.S. ACQUIRERS }} & \multirow{2}{*}{\multicolumn{2}{|c|}{ Acquirer is Domestic }} & \multirow{2}{*}{\multicolumn{2}{|c|}{$\begin{array}{l}\text { U.S. TARGETS } \\
\text { quirer is Foreign }\end{array}$}} \\
\hline & & & & & & & & \\
\hline & & & $\%-$ & t-statistic & Mean (\%) & t-statistic & Mean (\%) & t-statistic \\
\hline$(-1,+1)$ & $-1.12^{*}$ & 44 & 56 & -1.642 & $17.53^{* * *}$ & 6.43 & $8.45^{* * *}$ & 3.72 \\
\hline$(-1,0)$ & -0.64 & 47 & 53 & -1.074 & $13.38^{* * *}$ & 5.44 & $8.55^{* * *}$ & 3.82 \\
\hline$(0,+1)$ & $-1.54^{* * *}$ & 40 & 60 & -3.132 & $15.02^{* * *}$ & 6.19 & $8.21^{* * *}$ & 3.03 \\
\hline$(0,+3)$ & $-1.77^{* * *}$ & 42 & 58 & -2.489 & $15.23^{* * *}$ & 5.52 & $11.64^{* * *}$ & 2.62 \\
\hline$(0,+5)$ & $-2.52^{* * *}$ & 39 & 61 & -3.083 & $14.76^{* * *}$ & 5.42 & $11.54^{* * *}$ & 2.61 \\
\hline \multirow[t]{2}{*}{$(-10,+10)$} & 0.03 & 42 & 58 & 0.010 & $22.36^{* * *}$ & 4.96 & $16.15^{* * *}$ & 3.77 \\
\hline & & & & $n=125$ & & $N=150$ & & $n=17$ \\
\hline
\end{tabular}

Table 2 presents short term Cumulative Abnormal Returns (CARS) for US oil and gas acquiring and target firms. We use a standard event study methodology to measure the abnormal returns around the announcements of a takeover deal. We use daily stock returns to estimate the abnormal returns associated with the merger announcement (Brown and Warner, 1985). For each security in our sample, we use the market model. to estimate the abnormal returns $A R_{i, t}$ as follows: $A R_{i, t}=R_{i, t}-\left(a_{i}+B R_{m, t}\right)$ where $a$ and $B$ are OLS regression values from the estimation period prior to the event window and $t=0$ is the first trading day after the announcement of the M\&A transaction. Specifically, the pre-estimation period is 180 days prior to 30 days before the merger announcement day. ${ }^{*}{ }^{* *},{ }^{* * *}$ indicate estimates are statistically different from zero at the $0.10,0.05$ and 0.01 level of significance respectively.

\subsection{Energy reserves affect takeovers}

Our findings to test hypothesis two, energy reserves are related to takeover activities, value and performance, are shown in Table 3. The conclusions are sensitive to the methodology employed and aspect of the relation. The methods of Spearman correlation and F-statistic indicate that M \& A deals are negatively associated with a firm's oil reserves. That is, companies with low oil reserves pursue M \& A deals. There appears to be no statistically significant relationship between gas reserves and M \& A deals.

Viewing the relation between energy reserves and M \& A value, table 3 shows that the correlation technique generates statistical significance. Oil reserves show negative correlation with $M$ \& A value; whereas, gas reserves show positive correlation with M \& A value. These results endorse hypothesis two on the influence of energy reserves on takeovers.

Table 3: Energy reserves effect and relations on takeover activity and value

Energy Reserves and Takeover Activity

F- Statistic

Correlation

(Probability) (Probability) 


\begin{tabular}{lcr}
\hline OIL RESERVES does not Granger Cause M\&A DEALS & 1.259 & $-.695^{* * *}$ \\
M\&A DEALS does not Granger Cause OIL RESERVES & $(.345)$ & $(.001)$ \\
GAS RESERVES does not Granger Cause M\&A DEALS & $3.630^{*}$ & $(.058)$ \\
M \&A DEALS does not Granger Cause GAS RESERVES & 1.178 & .374 \\
Energy Reserves and Takeover Value & $(.341)$ & $(.115)$ \\
OIL RESERVES does not Granger Cause M\&A VALUE & 0.482 & $(.629)$ \\
M \& A VALUE does not Granger Cause OIL RESERVES & 1.272 & $-.654^{* * *}$ \\
& $(.316)$ & $(.002)$ \\
GAS RESERVES does not Granger Cause M\&A VALUE & 0.077 & $(.927)$ \\
M \& A VALUE does not Granger Cause GAS RESERVES & 0.368 & $.570^{* * *}$ \\
\end{tabular}

This table presents results of an analysis of causality direction by Granger Causality test. We test Annual number of takeover deals in Canada, United States and North America against reported proven national oil and gas reserves from 1990 to 2008. This table also presents non-parametric, Spearman's rho correlations between energy reserves and takeover activity and value. The top number is Spearman Rho Correlation, and the bottom number is significance in parenthesis. Source is the United States Energy Information Administration. Takeover deals and reserve variables are made stationary using first order changes, and takeover activity is lagged by two ${ }^{a}$ and three ${ }^{b}$ years. Test F-statistics and p-values are reported, and significance levels are indicated by * at the $10 \%$ level, ${ }^{* *}$ at the $5 \%$ level, ${ }^{* * *}$ at the $1 \%$ level or less.

\subsection{Energy prices affect takeovers}

To analyze hypothesis 3, energy prices relate to takeover activity, value and performance, we present Table 4. Observing the F-statistic for the Granger causality tests for the variable pairings of oil price, oil price change and number of deals we see the reciprocity relationship. That is, oil prices positively relate to number of M \& A deals, as well as, oil price changes positively relate to deals. Nevertheless, this outcome does not extend to gas prices to deals nor changes in gas prices to deals.

The far right panel of Table 4 shows the connection between energy prices and mean takeover value. The data establish a statistically significant link between oil prices and M \& A value as well as oil price changes and takeover value. Moreover, the investigation of the effect of gas prices to takeover value plus gas price changes to takeover value validates the significant correlation for both pairings.

Table 5 shows our results on the relationship between energy prices and takeover announcement performance. Energy prices, for both acquirers and targets, positively correlate to takeover performance and demonstrate a feedback relationship. The correlations between prices and performance are stronger for targets than for acquirers. This collection of results reinforce acceptance of hypothesis 3 on the effect prices have on takeover performance.

Table 4: Causality analysis of energy prices and takeover activity and value

\begin{tabular}{|c|c|c|c|}
\hline $\begin{array}{l}\text { Energy Prices and Number of Takeover Deals } \\
\text { Null Hypothesis: }\end{array}$ & $\begin{array}{l}\quad \text { F- } \\
\text { statistic } \\
\text { (Prob) }\end{array}$ & $\begin{array}{l}\text { Energy Prices and Mean Takeover Value } \\
\text { Null Hypothesis: }\end{array}$ & $\begin{array}{l}\text { F-Statistic } \\
\text { (Prob) }\end{array}$ \\
\hline OIL PRICE does not Granger Cause DEALSa & $\begin{array}{r}2.852^{*} \\
(.084)\end{array}$ & OIL PRICE does not Granger Cause VALUEa & $(0.232)^{1.722}$ \\
\hline DEALS does not Granger Cause OIL PRICE & $\begin{array}{r}7.289^{* *} \\
(.026)\end{array}$ & VALUE does not Granger Cause OIL PRICE & $\begin{array}{l}5.283^{* *} \\
(0.023)\end{array}$ \\
\hline OIL PCHG02 does not Granger Cause DEALS b & $\begin{array}{l}5.429^{* *} \\
(0.034)\end{array}$ & OIL PCHG02 does not Granger Cause VALUEb & $\begin{array}{l}3.299 * \\
(0.072)\end{array}$ \\
\hline DEALS does not Granger Cause OIL PCHG02 & $\begin{array}{r}1.621 \\
(0.284)\end{array}$ & $\begin{array}{l}\text { VALUE does not Granger Cause OIL } \\
\text { PCHG02 }\end{array}$ & $(0.772)^{0.264}$ \\
\hline GAS PRICE does not Granger Cause DEALSa & $\begin{array}{r}1.273 \\
(0.315)\end{array}$ & GAS PRICE does not Granger Cause VALUEa & $(0.467)^{1.019}$ \\
\hline DEALS does not Granger Cause GAS PRICE & $\begin{array}{r}0.277 \\
(0.763)\end{array}$ & $\begin{array}{l}\text { VALUE does not Granger Cause GAS } \\
\text { PRICE }\end{array}$ & $\begin{array}{r}38.477^{* * *} \\
(0.000)\end{array}$ \\
\hline GAS PCHG02 does not Granger Cause DEALS & $\begin{array}{r}1.094 \\
(0.367)\end{array}$ & GAS PCHG02 does not Granger Cause VALUEb & $\begin{array}{r}1.161 \\
(0.413)\end{array}$ \\
\hline
\end{tabular}


This table presents results of an analysis of causality direction by Granger Causality test. Annual number of takeover deals is tested against average annual spot prices for West Texas Intermediate Crude Oil and Henry Hub natural gas. We test Average takeover deal value against average annual spot prices for West Texas Intermediate Crude Oil and Henry Hub natural gas. We make Takeover deals and WTI Crude variables stationary using first order changes, and takeover activity is lagged by two ${ }^{\mathrm{a}}$ and three ${ }^{\mathrm{b}}$ years. Test F-statistics and p-values are reported, and significance levels are indicated by ${ }^{*}$ at the $10 \%$ level ${ }^{* *}$ at the $5 \%$ level ${ }^{* * *}$ at the $1 \%$ level, or less

\begin{tabular}{|c|c|c|}
\hline \multicolumn{3}{|c|}{$\begin{array}{l}\text { Table 5: Causality test of energy prices and } m \& \text { a performance } \\
\text { Panel A: Energy Prices and Acquirer Performance }\end{array}$} \\
\hline & U.S. $(-1,+1) \&$ WTI Crude & U.S. $(-10,+10)$ \& WTI Crude \\
\hline Test 1 & $2.906^{*}$ & $2.703^{*}$ \\
\hline $\mathrm{p}$ value 1 & $(0.081)$ & $(0.094)$ \\
\hline Test 2 & $7.426^{* *}$ & $6.907 * *$ \\
\hline $\mathrm{p}$ value 2 & $(0.024)$ & $(0.032)$ \\
\hline Result & Feedback Relationship & Feedback Relationship \\
\hline \multicolumn{3}{|c|}{ Panel B: Energy Prices and Target Performance } \\
\hline & U.S. $(-1,+1) \&$ WTI Crude & U.S. $(-10,+10)$ \& WTI Crude \\
\hline Test 1 & $3.676^{* *}$ & $6.389 * * *$ \\
\hline $\mathrm{p}$ value 1 & $(0.046)$ & $(0.008)$ \\
\hline Test 2 & $9.394^{* * *}$ & $16.327^{* * *}$ \\
\hline p value 2 & $(0.009)$ & $(0.000)$ \\
\hline Result & Feedback Relationship & Feedback Relationship \\
\hline
\end{tabular}

This table presents results of an analysis of causality direction by Granger Causality test. Two annualized CAAR windows $(-1,+1)$ and $(-10,+10)$ for targets and acquirers are tested against average annual spot prices for West Texas Intermediate Crude Oil. CAAR windows and WTI Crude variables are made stationary using first order changes, and performance is lagged by one and two years. Test F-statistics and p-values are reported, and significance levels are indicated by ${ }^{*}$ at the $10 \%$ level ${ }^{* *}$ at the $5 \%$ level ${ }^{* * *}$ at the $1 \%$ level or less

\subsection{Further analysis on energy prices and performance}

We perform further analysis of the link between oil and gas prices versus M \& A deals (takeover activity) and CAARs (target performance) for the event window $(-3,0)$ using the Spearman rho correlation. Table 6 presents these results. Again, we see that M \& A deals positively connect with oil prices, oil price changes, gas prices, and the interaction of oil and gas prices. We observe that there is insignificant and close to zero correlation between gas price changes to $M \& A$ deals. We explain that a reason for this observation is that the long-term production sales contracts in the gas industry are insensitive to short-term price variations.

\begin{tabular}{|c|c|c|c|}
\hline \multicolumn{4}{|c|}{ able 6: Oil and gas price relations with U.S. M \& A deals } \\
\hline Energy Prices & $\begin{array}{r}\text { Takeover Activity, } \\
\text { M\&A Deals }\end{array}$ & $\begin{array}{r}\text { Acquirer Performance } \\
\text { CAR }(-2,0)\end{array}$ & $\begin{array}{r}\text { Target Performance } \\
\text { CAR }(-3,0)\end{array}$ \\
\hline Oil Price & $.315^{*}$ & $\begin{array}{r}-.028 \\
(914)\end{array}$ & $-.687^{* * *}$ \\
\hline $\begin{array}{l}\text { Oil Price Change } \\
\text { (P0-P2) }\end{array}$ & $\begin{array}{r}.358^{*} \\
(.066)\end{array}$ & $\begin{array}{r}-.223 \\
(.390)\end{array}$ & $\begin{array}{l}-.665^{* *} \\
(.013)\end{array}$ \\
\hline Oil x Gas Price & $\begin{array}{l}.400 * * \\
(.045)\end{array}$ & $\begin{array}{r}.007 \\
(.978)\end{array}$ & $\begin{aligned}-.676^{* * *} \\
(.011)\end{aligned}$ \\
\hline Gas Price & $\begin{array}{l}.456^{* *} \\
(.025)\end{array}$ & $\begin{array}{r}.098 \\
(.708)\end{array}$ & $\begin{array}{l}-.659^{* *} \\
(.014)\end{array}$ \\
\hline $\begin{array}{l}\text { Gas Price Change } \\
\text { (P0-P2) }\end{array}$ & $\begin{array}{r}.004 \\
(.989)\end{array}$ & $\begin{array}{r}.169 \\
(.516)\end{array}$ & $\begin{array}{l}-.582^{* *} \\
(.037)\end{array}$ \\
\hline $\mathrm{N}$ of years & 19 & 17 & 13 \\
\hline
\end{tabular}

This table presents non-parametric, Spearman's rho correlations between energy prices and takeover activity. It also presents same correlations between energy prices and acquirer and target M\&A performance. The top number is Spearman Rho Correlation, and the bottom number is (significance). Sample is yearly number of U.S. M\&A deals and annual reported spot prices for Oil (WTI Crude) and Gas (Henry Hub) from 1990 to 2008. Sample is yearly average cumulative abnormal returns CAR $(-2,0)$ for acquirers and CAR $(-3,0)$ for targets. ${ }^{* * *}$. Correlation is significant at the 0.01 level or less (2-tailed). **. Correlation is significant at the 0.05 level or less (2-tailed). 1tailed results are reported for US deals for takeover activity. 
Oil and gas prices and their changes appear to have non-significant correlations on acquirer performance $(-2,0)$ window. However, they negatively correlate to target performance. This would mean that low energy prices are associated with higher target announcement returns. This result appears to be surprising as one would expect higher oil prices to raise the valuation of targets and hence their performance. However, this is in line with the explanation that when energy prices are low, target oil and gas firms are valued lower, and tends to invite more takeover activity from acquirers. With more takeover interest, there is more acquirer competition, bids and higher takeover premiums for target firms, and thus their takeover performance increases.

\subsection{Commodity price-driven and not stock market price-driven acquisitions}

Our conception of the commodity market timing motivation for M\&A is very different from stock market-driven acquisitions (Shleifer and Vishny, 2003; Dong et al., 2006; Rhodes-Kropf et al., 2005). In stock market-driven acquisitions, acquirers make takeovers to take advantage of the overpricing of their equity (relative to their targets) and tend to use stock payments. In that theory, acquirers time the market based on stock prices. In the theoretical notion of commodity price-driven acquisitions (Ng and Donker, 2012), acquirers and targets take advantage of changes in energy prices when making takeovers which would be unrelated to making stock payment deals. Thus, we hypothesize that energy prices would not relate to stock payments. Rather, at the same time, we hypothesize that market overvaluation is related to stock payments. This would distinguish commodity price driven acquisitions from stock market driven ones.

Table 7 presents the results of the logistic regression analyses of the determinants of stock payments in takeovers. The main variables of interest are market valuation and energy price changes in relation to whether firms make stock payments in a takeover. We use two definitions: market valuation and the top quartile rank of the market valuation of firms.

\begin{tabular}{|c|c|c|}
\hline \multirow[b]{2}{*}{ Independent variables } & \multicolumn{2}{|c|}{ Dependent Variable $=$ Payment with Stock } \\
\hline & (1) & $(2)$ \\
\hline Top Quartile, Market to Book & & $\begin{array}{l}1.69 * * \\
(3.89)\end{array}$ \\
\hline Market to Book Value & $\begin{array}{r}.41 \\
(1.66)\end{array}$ & \\
\hline Size (ln Sales) & $\begin{array}{r}-.04 \\
(.02)\end{array}$ & $\begin{array}{r}-.13 \\
(.30)\end{array}$ \\
\hline Fixed asset ratio & $\begin{array}{r}1.64 \\
(.58)\end{array}$ & $\begin{array}{l}1.24 \\
(.38)\end{array}$ \\
\hline Debt ratio & $\begin{array}{l}-1.65 \\
(.88)\end{array}$ & $\begin{array}{l}-1.16 \\
(.44)\end{array}$ \\
\hline ROE & $\begin{array}{r}1.41 \\
(4.08)\end{array}$ & $\begin{aligned} 1.25^{*} \\
(3.07)\end{aligned}$ \\
\hline M\&A type (merger/tender) & $\begin{array}{r}2.50 \\
(7.05)\end{array}$ & $\begin{array}{r}2.48^{* * *} \\
(7.02)\end{array}$ \\
\hline $\begin{array}{c}\text { Oil } x \text { Gas Price Change } \\
(\mathrm{P} 0-\mathrm{P} 2)\end{array}$ & $\begin{array}{r}.27 \\
(.00)\end{array}$ & $\begin{array}{r}.31 \\
(.00)\end{array}$ \\
\hline Control for years (19) & Yes & Yes \\
\hline $\mathrm{N}$ & 85 & 85 \\
\hline Nagelkerke R-Square & .54 & .40 \\
\hline
\end{tabular}

This table presents results of logistic regression analysis of determinants of stock payment in United States oil and gas industry takeovers between 1990 and 2008. We report regression coefficients on top, and the Wald test statistics below in parentheses. We calculate Oil and Gas price changes by subtracting yearly spot prices for WTI crude and natural gas. We identify Top quartile of market to book ratio firms as a dummy variable. Significant levels are indicated by $*, * *, * * *$ representing less than $10 \%, 5 \%$ and $1 \%$ levels respectively.

Model two results show overvaluation positively and significantly affects $(\mathrm{p}<.05)$ payment with stock as we would expect from a stock market driven motivation for takeovers. Moreover, the result for market-to-book (model 1) shows no relation to stock payment. Concurrently, and indeed, energy price changes show no relationship to stock payment takeovers in both models. Thus, these results suggest that when there is overvaluation of the oil and gas firms, firms do make stock payment in takeovers, and this is in line with the stock market driven acquisition hypothesis (Shleifer and Vishny, 2003). The type of acquisition, merger or tender offer, is positive and significantly related $(\mathrm{p}<.01)$ to stock payment. This is consistent with the stylized fact that acquirers make tender offers using stock payment. In sum, we further distinguish the commodity timing motivation for takeovers from the alternative explanation of stock overvaluation (Shleifer and Vishny, 2003; Dong et al., 2006; Rhodes-Kropf et al., 2005). 
Energy prices affect commodity price-driven takeovers; in contrast, stock prices affect stock overvaluation takeovers.

\subsection{Robustness}

Our results on these motivations hold true in the presence of the traditional determinants of takeover performance such as synergy gains (negative acquirer performance and no operating performance gains), agency costs (free cash flow is not related), and elevated stock market prices (high valuation is not related). With respect to the estimation of M\&A announcement return effects, we also find similar results, namely negative and significant CAARs for acquirers, using the Fama-French three-factor model estimation as shown in Table 7 below.

Using an alternative measure for oil prices, the energy price index results yield a similar conclusion using WTI crude oil prices. Further, we find that multi-collinearity is not an issue that affects our main findings on purchasing reserves and commodity market timing. We examine many other specifications of these regressions with or without White's correction for heteroscedasticity; these analyses yielded qualitatively similar results.

Table 7: United States acquirer Fama-French 3 factor model acquirer and target abnormal returns

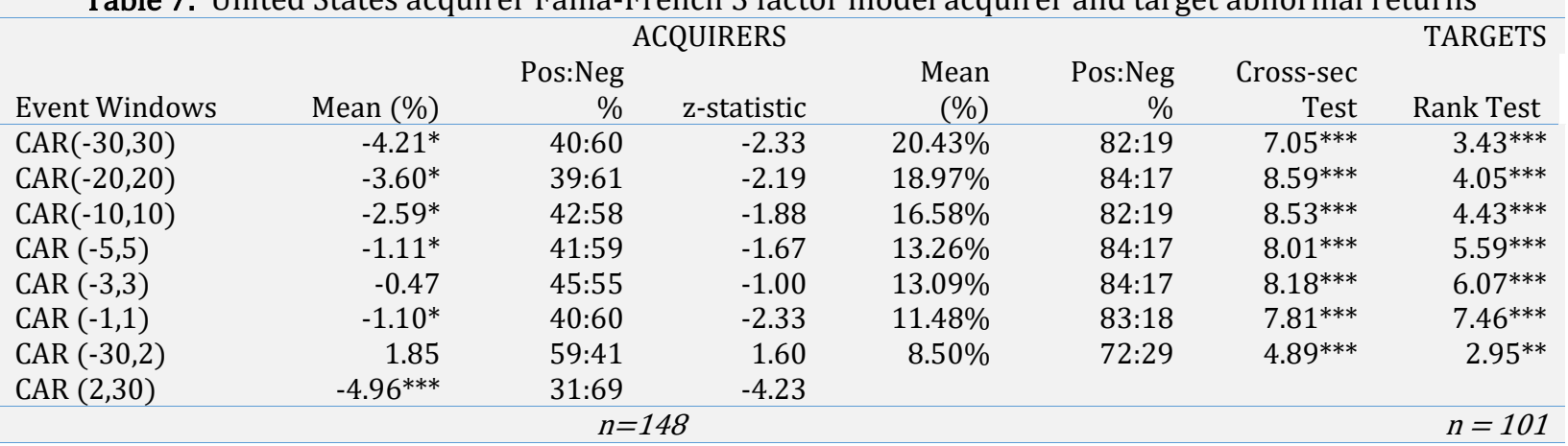

The symbols $* * *$, and ${ }^{* * *}$ denote statistical significance at the $0.10,0.05,0.01$ levels, respectively, using a generic one-tail test

Fama-French (1993) three-factor model:

$R_{j t}=\propto+\beta_{j} R_{m t}+s_{j} S M B_{t}+\boldsymbol{h}_{j} H M L_{t}+\varepsilon_{j t}$

$\mathrm{R}_{\mathrm{jt}} \quad=$ rate of return of the common share of the $\mathrm{j}^{\text {th }}$ firm on day $\mathrm{t}$

$\mathrm{R}_{\mathrm{mt}} \quad=$ rate of return of the S\&P 500 Composite index on day $\mathrm{t}$

$\mathrm{SMB}_{\mathrm{t}} \quad=$ average return on small market-capitalization portfolios minus the average return on three large market- capitalization portfolios

HMLt = average return on two high market-to-book equity portfolios minus the average return on two low market-to-book equity portfolios.

\subsection{Conclusions and policy implications}

We examine merger and acquisition deals in the US oil and gas industry for a nineteen-year period from 1990. We demonstrate that energy reserves and prices affect takeover activity, value, and performance. That is, macroeconomic factors such as energy commodity prices influence corporations in making merger and acquisition decisions as opposed to traditional rationale of synergy gains, agency costs, overvalued equity, and positive net present value capital budgeting decisions. Managers do time the market with favorable energy prices to create takeover opportunities and enhancing reserves. As far as we know, these motivations to execute merger and acquisition deals are unique to the oil and gas industry. It is possible that these motivations extend to other natural resource production industries, which produce globally traded commodities like forestry and mining.

We find US acquirers of oil and gas firms experience significantly negative returns at the acquisition announcement. Further, M \& A values are negatively (positively) associated with oil (gas) reserves. More so, oil prices, but not gas prices, positively relate to the number of $\mathrm{M} \& \mathrm{~A}$ deals.

The policy implications for potential target firms are divided into two takeover contexts: 1. those that want to repel takeovers and 2. those that want to sell out to the bidder. Firms wanting to prevent takeover need to put in place defenses and need to be ready when oil prices are high. Companies intending to sell can negotiate more strenuously for a higher price when oil (gas) reserves are low (high). 


\section{References}

Baker, W., Wurgler, J., (2002). Market timing and capital structure, Journal of Finance, 57(1): 1-32. http://dx.doi.org/10.1111/1540-6261.00414

Boyer, M. M., Filion, D., (2007). Common and fundamental factors in stock returns of Canadian oil and gas companies. Energy Economics, 29(3): 428-453. http://dx.doi.org/10.1016/j.eneco.2005.12.003

Brown, S. J., Warner, J. B., (1985). Using daily stock returns: the case of event studies. Journal of Financial Economics, 14(1): 3-31. http://dx.doi.org/10.1016/0304-405X(85)90042-X

Bruner, R. F., (2002). Does M \& A pay? A survey of evidence for the decision maker. Journal of Applied Finance, 12(1): 48-69.

Dong, M., Hirshleifer, D., Richardson, S., Teoh, S. H., (2006). Does investor misevaluation drive the takeover market? Journal of Finance, 61(2): 725-762. http://dx.doi.org/10.1111/j.1540-6261.2006.00853.x

Fama, E. F., French, K. R., (1993). Common risk factors in the returns on stocks and bonds. Journal of Financial Economics, 33(1): 3-56. http://dx.doi.org/10.1016/0304-405X(93)90023-5

Fan, F., Lin, L., Officer, M. S., (2013). Journal of Financial Economics, 109(1): 24-29. http://dx.doi.org/10.1016/j.jfineco.2013.02.013

Ferguson, R., Popkin, P., (1982). Pulling rabbits out of hats in the oil business- and elsewhere. Financial Analysts Journal, 38(2): 24-27. http://dx.doi.org/10.2469/faj.v38.n2.24

Graham, J. R., Harvey, C. R., (2001). The theory and practice of corporate finance: evidence from the field. Journal of Financial Economics, 60(2/3): 187-243. http://dx.doi.org/10.1016/S0304-405X(01)00044-7

Granger, C. J., (1969). Investigating casual relationships by econometrics models and cross-spectral methods. Econometrica, 37(3): 425-435. http://dx.doi.org/10.2307/1912791

Jensen, M. C., Meckling, W. H., (1976). Theory of the firm: managerial behavior, agency costs and ownership structure. Journal of Financial Economics 3(4): 305-360. http://dx.doi.org/10.1016/S00225193(76)80085-9

Jensen, M. J., (1986). Agency costs of free cash flow, corporate finance and the market for takeovers. American Economic Review, 76(2): 323-329.

Jensen, M. C., (1993). The modern industrial revolution and the challenge to internal control systems. Journal of Finance, 48(3): 831-880. http://dx.doi.org/10.1111/j.1540-6261.1993.tb04022.x

Kretzschmar, G. L., Kirchner, A., (2009). Oil price and reserve location - effects on oil and gas sector returns. Global Finance Journal, 20(3): 260-272. http://dx.doi.org/10.1016/j.gfj.2009.08.001

Mitchell, M. L., Mulherin, J. H., (1996). The impact of industry shocks on takeover and restructuring activity. Journal of Financial Economics, 41(2): 193-229. http://dx.doi.org/10.1016/0304-405X(95)00860-H

$\mathrm{Ng}$, A., Donker, H., (2013). Purchasing reserves and commodity market timing as takeover motives in the oil and gas industry. Energy Economics, 37(May): 167-181. http://dx.doi.org/10.1016/j.eneco.2013.01.010

Reid, S. R., (1973). Petroleum mergers, multinational investments, refining capacity and performance in the energy crisis. Financial Management, 2(4): 50-56. http://dx.doi.org/10.2307/3665424

Rhodes-Kropf, M., Robinson, D., Viswanathan, S., (2005). Valuation waves and merger activity: the empirical evidence. Journal of Financial Economics, 77(3): 561-603. http://dx.doi.org/10.1016/j.ffineco.2004.06.015

Ruback, R. S., (1983). The cities service takeover: a case study. Journal of Finance, 38(2): 319-330. http://dx.doi.org/10.1111/j.1540-6261.1983.tb02236.x

Shleifer, A., Vishny, R., (2003). Stock market drive acquisitions. Journal of Financial Economics, 70(3): 295-311. http://dx.doi.org/10.1016/S0304-405X(03)00211-3

Weston, J. F., Johnson, B. A., Siu, J. A., (1999). Mergers and restructuring in the world oil industry. Journal of Energy Finance and Development, 4(2): 149-183. http://dx.doi.org/10.1016/S1085-7443(99)00008-3

Weston, J. F., Kwang, S. C., Hoag, S. E., (1990). Mergers, Restructuring, and Corporate Control. Englewood Cliffs: Prentice Hall.

Wan, K. M., Wong, K. F., (2009). Economic impact of political barriers to cross-border acquisitions: an empirical study of CNOOC's unsuccessful takeover of Unocal. Journal of Corporate Finance, 15(4): 447-468. http://dx.doi.org/10.1016/j.jcorpfin.2009.03.004

Appendix 1: Variable Definitions Used in this Study

$\begin{array}{ll}\text { Variables } & \text { Definition } \\ \text { Oil Price } & \text { Annual reported spot prices for Oil (WTI Crude) from the } \\ \text { Gas Price } & \text { US Energy Administration } \\ & \text { Annual reported spot prices for Gas (Henry Hub) }\end{array}$




\section{Reserves}

Takeover Deals

Takeover Value

Top Quartile, Market to Book Market to Book Value Size (In Sales)

Fixed asset ratio

Debt ratio

ROE

M\&A type (merger/tender)
Annual national proven reserves in US dollars of oil and gas obtained from the US Energy Administration

Annual number of takeover deals

Average takeover deal value calculated as annual total deal value divided by total number of deals

Dummy of 1, 0 for firms in the top quartile in market to book value

Market to book value of Equity

Natural log of firm Sales

Fixed assets divided by total assets

Debt to equity ratio as total debt divided by the book value of equity

Return on Equity as Net Income divided by equity

Dummy of 1 for tender offers, 0 for merger deals 